\title{
Prevailing Perceptions and the Growth of Private Label Brands in Africa and Europe: An Overview
}

\author{
Sbonelo Ndlovu \\ University of Zululand, Kwa-Dlangezwa Campus, South Africa \\ sbonelogiftndlovu@yahoo.co.za
}

\begin{abstract}
This paper reviewed the existing literature in different parts of the continents, focusing specifically in Africa and Europe, critically reviewing past and recent literature of studies on customers' perceptions towards private label brands. Such review article enabled the writer to understand the prevailing state of private label brands across different continents; in the process enabling grocery retailers, marketing practitioners and academics a clear view of the state of customers' perceptions around the globe. The results found that the international state of private label brands has somehow improved in some parts of the globe, especially in Europe and Americas, where private label brands have enormously improved customers perceptions of their private label brands and in the process actively competing with national brands for the market share. Opposing such success, In Africa there seems to be somehow lack of improvement in the early perceptions of private label brands in the process not fully challenging national brands. Noticeably, in Africa there seems customers still perceive private label brands as alternatives of national brands in tough economic conditions. Hence, grocery retailers need to extensively invest on their private label brands in order to competitively challenge and change existing customer perceptions. Key investments should be in branding, promoting and educating customers about private label brands.
\end{abstract}

Keywords: Private label brands; perceptions; national brands; Africa; Europe

\section{Introduction}

Private label brands are defined as grocery retail owned or store brands, that are manufactured and sold under a specific grocery retailer which owns that particular private label brand (Kumar \& Steenkamp, 2007) as cited by (Beneke, Flynn, Greig \& Mukaiwa, 2013). Remarkably, Cuneo, Benavante, Milberg \& PalaciosFenech (2015) argue that there has been a steady increase in the market penetration of private label brands in recent years, growing from $16.3 \%$ to $16.7 \%$ in 2016 (Global Nielsen Report, 2018). Noticeably, most growth has been realized in the grocery retailers' private labels consumer goods. This is supported by the 90 $\%$ presence of private label brands in the packaged consumer goods categories (Cuneo et al., 2015). This sharp prominence of private label brands has been realized across various countries. Interestingly, the following scholars (Steenkamp \& Dekimpe, 1997) as cited by Schmidt, Mason, Steenkamp \& Mugobo (2017) hold the view that traditionally private label brands were usually considered in times of unfavorable economic conditions, for they provided a cheaper alternative to manufacturer brands. However, in Africa the provision of private label brands has been present but accompanied with low market penetration (Beneke et al., 2013; Global Nielsen Report, 2014). Global Nielsen Report (2014) holds that grocery retailers in Africa find it hard to obtain equipped suppliers that can contest the quality of manufactured brands packaged consumer goods, which is one of the challenge faced by grocery retailers, amongst other challenges.

Contemporary research provides the view that private label brands have been improving over the years. Even though the Global Nielsen Report (2018) projected a growth of private label brands in Middle East and North Africa (with South Africa included) from $2.3 \%$ to $3.2 \%$, it is still the lowest in terms of comparison with growth rates of other countries. Evidently, there are various studies with different conclusions and results regarding private label brands in both types of economies under study. Therefore, grocery retailers must work very hard to improve the perceptions of customers towards private label brands (Rossi, Borges \& Bakpayev, 2017). In the process enhancing the brand image of private label brands as it plays a critical role in shaping customers' perceptions (Rossi et al., 2017; Olbrich, Jansen \& Hundt, 2016). Therefore, African Grocery retailers need to understand the prevailing perceptions of African consumers regarding private label brands. Henceforth, the recent paper aims to critically review past and present literature towards understanding the existing perceptions around private label brands around the globe in the grocery retail sector, by reviewing literature from two continental regions, Europe and Africa. This paper is organized as follows; a summary of recent literature of private label brands in Africa, private label brands in Europe, the future of private label brands, methodology, discussion and conclusions and recommendations. 


\section{Literature Review}

The Historic introduction of private label brands by grocery retailers since represented an opportunity for retailers to gain higher margins and greater chance of profitability while offering inferior quality and cheap alternatives to manufacture products (De \& Singh, 2017). Ranga (2017) in the study "private label brandsnational and international scenario: a review based paper" offers that private label brands were also introduced to offer consumers a variety of product ranges to consume from, aside from driving up margins and generating high profits. Opposing, Lin, Dawson \& Marshall (2009) insist that private label brands have been thoroughly researched in developed countries; quietly sadly that has not been the case in developing countries (Lin et al., 2009). As now they offer more than inferior quality or being cheaper alternatives of national brands. However, that is not realized in all countries. A recent study of Witek-Hadjuk \& Grudecka (2017) "Positioning strategies of retailers brands in the emerging market - a cluster analysis" conducted in Poland, concluded that private label brands in emerging economies are gaining insurgence and are fast catching up with the development of their economies. Sadly, the market share variations of private label brands have been a concerning factor.

When comparing the growth of private label brands in both perspectives (Developed and Developing, economies). Where it is found that in Europe the market shares of private label brands in some economies have reached almost a 50\% range in market shares and some are fast approaching that market share mark with their private label brands (Global Nielsen Report, 2014; Cuneo et al., 2015). Whereas, in some developing economies the private label brands market shares account for $10 \%$ or less (PLMA, 2013; Nielsen, 2010) as cited by (Herstein, Drori, Berger \& Barnes, 2015). Hence, retailers from developing countries can learn from the strategies employed by retailers of developed countries, especially in European economies. The concluding remarks in the study of Beneke (2017) "the Arduous Journey of Private Labels: Insights From the South African Market and Further Afield" cement the predictions of Rabobank (2011) that by 2025 private label brands are expected to be at $25 \%$ to $50 \%$ in market share, globally. Therefore the future of private label brands seems to be brighter. In the process retailers need to continuously adopt winning strategies a basic profile of private label brands.

\section{Table 1: Briefly Elaborates on the Features of Private Label Brands}

\begin{tabular}{ll}
\hline Features of Private Label Brands & Sarkar, Sharma \& Kalro (2015) found that those private label \\
Packaging & packaged similar to national brands are positively perceived \\
& and the opposite is true. \\
Grocery retailers use PLBs to differentiate their chains against & other retailers (Juhl, Esjberg, Grunnert, Bech-Lasern \& Brunso, \\
Differentiation & 2006) in support, Kwon, Lee and Kwon (2008) they found that \\
& it also increases store loyalty amongst customers. \\
& Generally the pricing of PLBs is set lower than national brands \\
Pricing & Kwon, Lee and Kwon, 2008). Sarkar et al. (2015) finds that \\
& grocery retailers use promotions as pricing strategy, to \\
& generate volumes of sales.
\end{tabular}

Private Label Brands in Africa: Nielsen Global Report (2014) reports that private label brands in Africa are continuing in growth. This opportunity of growth has sparked interest of big international trade discount retailers to make inwards in Africa, for example, Turkish giants BIM has applied its trade in Morocco and Egypt (Nielsen Global Report, 2014). This is highlighted by Mostafa \& Elseidi (2017) who revealed that modern retail chains in Africa are at an infant stage. In the process private label brands in Africa have been under trusted for a while since customers are more loyal to national brands (Nielsen Global Report, 2014; 2018). They do not trust the provision of private label brands as they are deemed a risky option over national brands (Nielsen Global Report, 2014). These further the skepticism around private label brands in Africa. Interestingly, the findings of Mostafa \& Elseidi (2017) in their study "Factors affecting consumers' willingness to buy private label brands (PLBs) Applied study on hypermarkets". 
Conducted in Egyptian hypermarkets found that store image also has a huge effect on consumer perception of private label brands offered by retailers and the findings were consistent to the managerial implications of Sethuraman \& Gielens (2014). The study of Beneke (2017) Found that private label brands in Africa soar during tough economic hardships, since consumers in that period are financially constrained. Therefore it is likely that in Africa customers have since been skeptical of private label brands. As a result this has led to the slowness in the in the market penetration of these private label brands (Beneke, 2010). Where in the southern of Africa it was found that South Africa has the promising development in terms of the market penetration of their private label brands, although customers are found to be still somehow skeptical of these brands (Global Nielsen Report, 2018; Nyengerai, Jaravaza, Mukucha, Chirimubwe \& Manjoro, 2013). In other countries there is famine report on the state of private label brands, besides Morocco, Egypt and Zimbabwe. Present research finds similar skepticisms as in other African countries. Such positivity and rapid growth of private label brands in other nations, specifically in developed western countries; is said to be achieved through grocery retailers constantly innovating and improving the quality of their private label brands, in the long run competing with national brands (Nielsen Global Report, 2014; 2018). Such findings were cemented by the result of Rossi, Borges \& Bakpayev (2017) pointing out the growth of private label brands in these countries by ascertaining that the quality gap between private label brands and national brands is slowly being closed.

In their study furthered the notion that the tremendous growth of private label brand is attributed to the reduction in the assumption of the quality gap between private label brands and national brands. Furthermore, the conclusions of posited that grocery retailers should view their private label brands from a branding point of view in order to build and enhance positive perceptions among customers regarding their private label products (Rossi et al., 2017). Such skepticism proves to be worrisome as the other nations have embraced private label brands with utmost positivity. The Nielsen Global Report (2018) also found that the Consumer confidence index was very high in most parts of the world but the index was worrisome in the Africa/Middle East region. Customers in this region are clearly not confident on the provision of private label brands, as a result of the abovementioned factors making them not trust these brands and in the process preferring national brands as safer options. Worryingly, Customers have famine knowledge of private label brands in Africa, leaving them prone to negative perceptions, in the process hindering their utmost growth in their market share (Beneke, 2010; Beneke \& Carter, 2015). Hence, Sebri \& Zaccour (2017) in their study offered that retailers in emerging economies must provide private label brands that are linked to what customers expect of them (PLBs). This calls for African and South African grocery retailers to advance their branding activities to successfully build positive associations with customers and private label brands. This shall result in total improvement of the grocery retail sector, in the process improve the perceptions customers attach to private label brands across countries.

Private Label Brands in Europe: European nations have over the years been a benchmark for growth of private label brands. Cuneo et al. (2015) in their study found that in European countries, private label brands have undergone a deep transformation process from being perceived as being low-priced, low-quality, poorly packaged alternatives of national brands to competitors with national brands. Such transformation had been achieved by dedication of grocery retailers in these countries to transform their private label brands. Hence, consumers' perceptions of private label products in these countries started evolving to seeing private label brands as favorable selections aside from national brands (Beneke, 2010; Global Nielsen report, 2014; Cuneo et al., 2015). As it been found by Soydanbay (2013) that traditionally private label brands in the $19^{\text {th }}$ century were founded during tough economic conditions where by merchants in the food retail business, during these times World War 1 and 2 left dire economic conditions. Hence, they were associated with being low-cost and only considered for purchase in tough economic conditions. Over the years private label brands have carried that stigma, however throughout the years retailers in Europe have fought off those perceptions. Food and Drinks Europe (2018) announced their findings that private label brands in Europe have fast exceptionally surpassed national brands during the 2017 financial year. This include in the major markets where private label brands are dominant; in the UK, Spain, Germany, Italy, Netherlands and France where in 2009 planet retail reported their findings that the average market penetration rates in Europe were at 19\%. However the country to country market penetration were reported to be the following in the findings of Europanel (2009) as cited by Cuneo et al. (2015). United Kingdom (46\%), Switzerland (45\%), Germany (37\%) and Spain at 33\% (Europanel, 2009) as mentioned in (Cuneo et al., 2015). 
However, recent study by PLMA (2019) found that now the market shares of most countries lies at $30 \%$ and more; with powerhouse private label markets Spain, Switzerland and the UK at $50 \%$ and above, Belgium $44 \%$ and Germany 44\% in contradiction, the finding of Abotorabi (2018) finds that the market penetration value amounts to $39.4 \%$ in the aforementioned major European economies. The aforementioned market penetration rates as studied represent that private label brands in Europe are fast moving towards disrupting national brands. However, what is this attributed to; providing high quality private label products, offering consumer orientated private label brands with a good price and quality ratio, constant innovation of these brands, expanding retail formats, embracing modern retail trade and e-commerce (Nielsen Global Report, 2016; 2018; Abotorabi, 2018). These investments by grocery retailers have positively yielded positive perceptions among customers in a way they believe private label brands offer them value for their money and in turn are insignificant to national brands. In the process private label brands have now compete head on with national brands in the European markets. In the process occupying much sought for retail shelf space (Abotorabi, 2018).

The Future of Private Label Brands: Over the years private label brands have been growing tremendously, growing in all most every product category. Therefore in the process, Rabobank (2011) in the words of Cuneo et al. (2015) forecasted that private label brands would reach as far as 50\% in market share, competing with national brands. Such findings are consistent to the results of Cuneo et al. (2015) where they also found private label brands to be on the rise, more especially in Europe and in the Americas. The constant rise of private label brands shows that retail managers, practitioners and academics in these countries actively research and provide innovative private label brands that are good alternatives to national brands, if not competitors of national brands.

Figure 1: Illustrates the Forecasts of Market Penetration across Countries

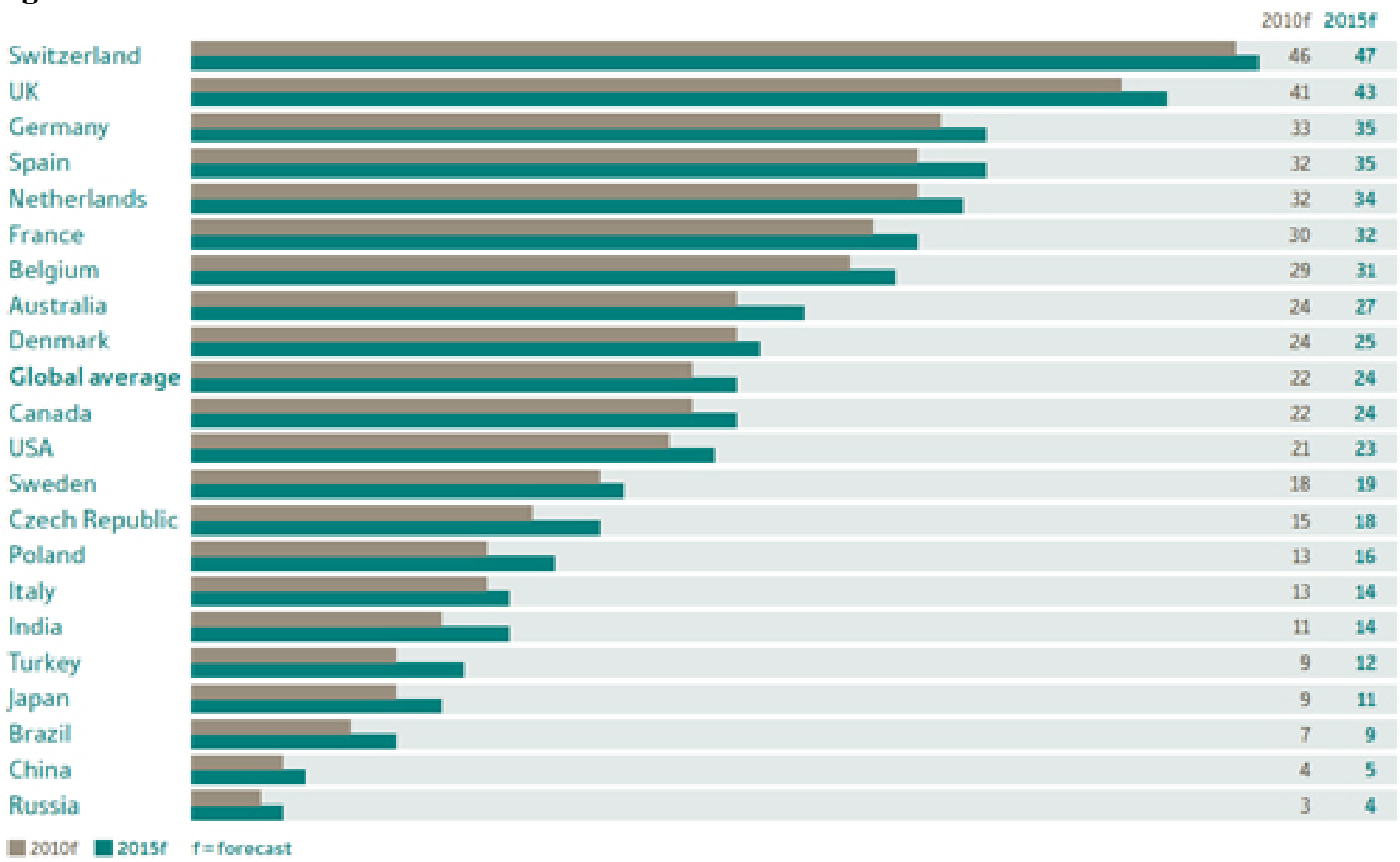

Source: (http://www.mcbride.co.uk/leadership-in-private-label/growth-markets)

The above figure manifest the positive forecast aforementioned in the studies of (Rabobank, 2011; Cuneo et al., 2015) who signal for the growth of private label market shares across the globe between 2010-2015, however the future of private label brands of other economies will still fall below the global average in market penetration. Liu, Sprangenberg, Sprott, Czella \& Voss (2018) interestingly found that if retailers 
continuously engage consumers with their private label brands and offer them with a completely satisfying experience, in future customers will positively perceive private label brands preferring them over national brands in the long run. Noticeably, Intelligence Node (2017) ascertained that private label brands over the years have been increasingly present in all most all product categories to an extent that customers feel indifferent in terms of quality, when compared against national brands. Authors in present research said to find that grocery retailers, mostly in developed countries have not only innovated and provided quality private label brands. But there is a new wave of growth for private label brands. Applebaum (2019) found that retailers are now venturing into e-commerce in order to provision their private label offering further than the traditional methods of reaching customers. This new wave of disruption in the retail industry presents grocery retailers with an opportunity to further compete with national brands on another scale. Abotorabi (2018) in their study of "private label comes of age" alluded on grocery retailers venturing into ecommerce, whereby it will become a new battle ground in the future for both private label brands and national brands.

This is substantiated in the Nielsen Global Report (2018), where they stressed that the new technological revolution has become the latest growth driver of private label brands, with tangible evidence of the growth in the market shares of developed European countries discount stores. These are all indicators that private label brands are set to stay and become more competitive in great aspects aside from being alternatives to national brands. Therefore, existing literature proves that private label brands are getting more and more competitive. This was apparent in the study conclusions of who offered that if private label brands or national brands are offered through online stores, it will allow retailers to realize increased profits via this new online store strategy. These strategies have been already implemented in the developed economies, as stated in the studies of (Applebaum, 2019; Abotorabi, 2018; Global Nielsen Report, 2018). Such new directions surely prove to catch grocery retailers of developing countries on their back heel. Since they still rely heavily on traditional commerce in providing private label brands to consumer Diallo \& Seck (2012) studying service quality and attitudes of consumers towards store brands, the conclusions and managerial implications indicated that for retailers to positively move forward in terms of their private label brands, they need to revise their approach in terms of the negative risks associated with private label brands. In the process that can improve the service quality and attitudes of customers towards store brands. This study was undertaken in two emerging economies of Brazil and Vietnam.

\section{Research Methodology}

This study undertook the reviewing of past and present existing literature of studies focusing on overviewing literature and juxtaposing the perceptions of customers and the growth of private label brands in Africa and Europe. A semi-systematic methodological approach was used when reviewing the literature. The approach enabled the review and overview of past and present literature on the perceptions of customers and the growth of private label brands. Authors propose that reviewing previous studies is essential in reviewing and uncovering what might have been not covered in primary research by authors as it helps in synthesizing and identifying trends of past literature in a new approach, in the process uncovering new research gaps and areas (Mayer, 2009). Snyder (2019) posits that the semi-systematic methodological approach is useful in reviewing and synthesizing broad topics. Hence, the author undertook a semi-systematic methodological approach of a review article. Whereby the author reviewed and overviewed studies from both continental regions and analyzed them using the content analysis technique. Literature is collected from various journals, articles and research reports.

\section{Discussion and Conclusion}

The aim of this study was to understand the perceptions of customers regarding private label brands and their growth across two regions, Africa and Europe. The results for this study offers that consumer perceptions around private label brands tends to vary across these economies, however they revolve around the same perceptual factors; risk, price, quality, and store image. Firstly, the study finds that European grocery retailers have improved most of these perceptual factors. Customers in these economies are now of the perceptions that private label brands are not associated with any functional or financial risks (Diallo, 2012). Furthermore, customers are of the view that grocery retailers now offer good quality private label 
branded products and accompanied with good pricing, reasonable to them (Abotorabi, 2018). Secondly, in Africa as is with other emerging economies, the study finds that customers are still concerned with the risks associated with the usage of private label brands, financial risk is a concern and a stumbling block in customers positively accepting private label brands in Africa (Beneke et al., 2013). Furthermore, they are skeptical of the quality of private label brands when compared to that of national brands, in the process not trusting private label brands due to the negative risks and perceptions surrounding these brands. Lastly, the study establishes that European developed economies; United Kingdom, Switzerland, Germany and Spain are dominant in the of growth private label brands (Nielsen Global Report, 2014; 2018; Beneke, 2017).

This cements how common private label brands are amongst consumers in Europe. The study notably finds that private label brands are set to be further on the rise in coming years, with European economies predicted to benefit more on these predictions. Meanwhile, In Africa private label brands are present but are yet to be popular amongst customers (Mostafa \& Elseidi, 2017; Nielsen Global report, 2014). The findings of this study resonates with the study of Nyengerai et al. (2013) who concludes that familiarity of consumers towards private label brands builds perceptions around private label brands. As a result it is understood that customers in Africa have little knowledge of private label brands. Hence, the found perceptions amongst customers are due to their limited knowledge concerning private label brands. In Africa it is discovered that there are still many slowing factors that prevent the sharp prominence of private label brands aside from the existing customer perceptions, the infancy of the grocery retail structure is also a contributing factor to the slowness in growth of private label brands, as it is either adopting modern trade recently or not at all in some parts whereas, European counterparts have long gone embraced modern trade (Mostafa \& Elseidi, 2017; Nielsen Global Report, 2014).

Where retailers have went on to adopting online stores in order to compete for the market shares with national brands. Interestingly, this review finds that the growth of private label brands is still going to surge across countries with dominant European economies going to realize further growth, with more skepticism in Africa/Middle east (Rabobank, 2011; Global Nielsen Report, 2018). Disturbingly, in Africa there is still concentration in the grocery retail sector, in the process hindering the growth of the market shares of private label brands, as Sethuraman and Gielens (2014) in their study found that where there is concentration, the market shares of private label brands are seemingly low. Amidst the hindrances surrounding private label insurgence in some regions, research resonates that perceptions of private label brands have been tremendously improved by grocery retailers in a way that private label brands are insignificant to national brands. More, especially in Switzerland where PLMA (2019) found that for almost every $2^{\text {nd }}$ product sold it is a private label brand. It is clear that grocery retailers in Africa can learn and adopt from the European strategies in order to obtain favorable perceptions among consumers for their private label brands in order to grow the private label presence and familiarize them amongst consumers.

\section{Recommendations and Future Research}

The study reviewed existing literature and acknowledged certain research gaps. The author notes the less familiarity of private label brands in Africa. It is evident that grocery retailers in Europe are ahead with most aspects when it comes to private label brands, however the growth in some European countries seem stagnant. Hence future research is essential to uncover what impedes rapid growth of private label brands in some parts of the European regions. Grocery retailers in Africa should continually improve, innovate and actively promote their private label brands, such that consumers will see them indifferent from the provision of national brands. Future research may be undertaken on how retailers perceive e-commerce and the readiness of consumers towards shopping on online stores rather than from traditional retail formats, especially in Africa, where the grocery retail structures are at an infancy level compared to European grocery retail structures. More private label research literature is needed in an African context. 


\section{References}

Abotorabi, 0. (2018, October 8). Private label comes of age. Packaging Europe. Retrieved From https://packagingeurope.com/private-label-comes-of-age/.

Applebaum, M. (2019, February 20). Private label: A growing CPG crisis. Path to Purchase IQ. Retrieved From https://consumergoods.com/private-label-growing-cpg-crisis.

Beneke, J. (2010). Consumer perceptions of private label brands within the retail grocery Sector of South Africa. African Journal of Business Management, 2(4), 203-220.

Beneke, J. (2017). The Arduous journey of private label brands: Insights from the South African market and further afield. Journal of Food Products Marketing, 6(23), 668-682.

Beneke, J., Flynn, R., Greig, T. \& Mukaiwa, M. (2013). The influence of perceived product Quality, Relative price and risk on customer value and willingness to buy: a study of private label merchandise. Journal of Product and Management, 3(22), 218-228.

Cuneo, A., Milberg, S., Fenech, J. P. \& Benavante, J. M. (2015). The Growth of Private Label Brands: A Worldwide Phenomenon. Journal of International Marketing, 1(23), 72-90.

De, D. \& Singh, A. (2017). Consumer's Perspective and Retailer's Consideration towards Purchase of Private Label Brands. Procedia computer science, 122, 587-594.

Diallo, M. F. \& Seck, A. M. (2017). How store service quality affects attitude toward store Brands In emerging countries: Effects of brand cues and the cultural context. Journal of Business Research, (86), 311-320.

Diallo, M. F. (2012). Effects of store image and store brand price-image on store brand purchase intention: Application to an emerging market. Journal of Retailing and Consumer Services, 19(3), 360-367.

Europanel. (2009). Key Facts for Decision Makers. Research report.

Food and Drinks Europe. (2018). Food and drinks Data and trends, 2018. Retrieved from https://www.fooddrinkeurope.eu/uploads/publications_documents/FoodDrinkEurope_Data_and_Tr ends_2018_FINAL.pdf.

Herstein, R., Drori, N. \& Barnes, B. R. (2015). Exploring the gap between policy and practice in private branding strategy management in an emerging market. International Journal of Emerging Markets, $4(34), 559-578$.

Intelligence Node. (2017, October 13). Private label products: are they national brand Killers. Retail business. Retrieved from https://www.intelligencenode.com/blog/private-label-brand-national-killers/.

Kwon, K., Lee, M. \& Kwon, M. (2008). The effect of perceived product characteristics on Private brands purchases. Journal of Consumer Marketing, 2(25), 105-114.

Lin, C., Marshall, D. \& Dawson, J. (2009). How does perceived convenience retailer Innovativeness create value for the customer? Journal of Marketing Management, 9(25), 875-891.

Liu, R. L., David, Sprott, Spangenberg, E. R., Czellar, S. \& Vos, K. E. (2018). Consumer preference for National vs. private label: The influence of brand engagement and self-concept threat. Journal of Retailing and Consumer Services, 41, 90-100.

Mayer, P. (2009). Guidelines for writing a review article. Zurich-Basel Plant Science Center. Retrieved from http://www.plantscience.ethz.ch/education/Masters/courses/Scientific_Writing.

Mostafa, R. \& Elseidi, R. (2017). Factors affecting consumers' willingness to buy private Label brands- Applied study on hypermarkets. Spanish Journal of Marketing, 3(22), 341-361.

Nenycz-Thiel, M. \& Jenni, R. (2006). Consumer Perceptions of Private Label Brands. Ehrenberg-Bass Institute for Marketing Science, University of South Australia, 1-8.

Nielsen. (2014). The state of private label around the world: Where it's growing, where it's Not and what the future holds. Retrieved from https://www.nielsen.com/content/dam/nielsenglobal/kr/docs/globalreport/2014/Nielsen\%20Global\%20Private\%20Label\%20Report\%20November\%202014.pdf.

Nielsen. (2018). The rise and rise again of private label brands, 2018. Retrieved from https://www.nielsen.com/us/en/insights/report/2018/the-rise-and-rise-again-of-private-label/.

Nyengerai, S., Jaravaza, D., Mukucha, P., Chirimubwe, R. \& Manjoro, E. (2013). Determinants of Perception towards Private Label Brands in Zimbabwe: The Role of Familiarity, Store Image, Demographic Factors and Consumer Characteristics. Greener Journal of Management Studies, 5(3), 224-230.

Olbrich, R., Jansen, H. C. \& Hundt, M. (2016). Effect of pricing strategies and product quality on private label and national brands performance. Journal of Retailing and Consumer Services, 34, 294-301.

PLMA. (2016). PLMA's 2016 Private Label Yearbook A Statistical Guide to Today's Store Brands. 


\section{Journal of Economics and Behavioral Studies (ISSN: 2220-6140)}

Vol. 11, No. 5, pp. 76-83 October 2019

PLMA. (2019). Private label today, 2019. Retrieved from https://www.plmainternational.com/industrynews/private-label-today.

Rabobank. (2011). Retail private label brands in Europe: An inseparable combination. Retrieved from http://www.rabobank.de/uploads/media/Rabobank_Private_Label_vs_Brands_Schreijen_01.pdf.

Ranga, M. (2017). Private label brands- national and international scenario: A review based Paper. International Journal of Research in Commerce and Management, 8, 0976-2183.

Rossi, P., Borges, A. \& Bakpayev, M. (2017). Private label versus National brands: The effect of branding on sensory perceptions and purchase intention. Journal of Retailing and Consumer Services, 27, 74-79.

Sarkar, S., Sharma, D. \& Kalro, A. (2016). Private label brands in an emerging economy: an Exploratory study in India. International Journal of Retail \& Distribution Management, 2(44), 203-222.

Schmidt, H. j., Mason, R., Steenkamp, P. \& Mugobo, V. (2017). Does brand orientation Contribute to retailers' success? An empirical study in the South African retail market. Journal of retailing and consumer services, 38, 210-222.

Sebri, M. \& Zaccour, G. (2017). Cross-country differences in private-label success: An Exploratory approach. Journal of Business Research, 80, 116-126.

Sethuraman, R. \& Gielens, K. (2014). Determinants of store brands share. Journal of Retailing, 2(90), 141-153.

Snyder, H. (2019). Literature review as a research methodology: An overview and guidelines. Journal of Business Research, 104, 333-339.

Soydanbay. (2013). Why do we buy private label brands? Retrieved from https://soydanbay.com/2013/12/17/the-unconscious-of-private-label-brands/.

Witek-Hadjuk, M. K. \& Grudecka, A. (2017). Positioning strategies of retailers' brands in the Emerging market - a cluster analysis. International Journal of Emerging Markets, 5(13), 925-942. 